\title{
7 授乳婦の乳房皮膚温と知覚に関する研究
}

聖路加看護大学堀内 成子

序：産袮期の母親が生活リズムの変更を 余儀なくされる理由のひとつに、授乳や㕕 児による夜間の睡眠中断がある。睡眠中の 覚醒は、感覚器からの信号が大睬皮筫に刺 激として伝えられるこで引き起こされる。 産袮期には新生児の泣きや動きが、母親の 視党や聴覚刺激となり睡眠中の覚醒を引き 起こすと考えられる。しかし、それだけで なく母親自身の身体的な変化の中でも最も 活発な乳汁分泌現象が覚醒に関与している のではないかと仮定した。

今回は、授乳の経駼を表す客観的及び主 観的な指標（測定用具）の開発を意図し、 予備調査を行った。乳汁産生の指標として 乳房皮虞温を取り上げ、それと知覚との関 連性に着目した。

目的: 授乳婦の乳房の皮虔温と知覚の変 化を明らかにすることを目的に、1）産裖 期の経時的変化、2) 授乳前後の変化、3) 皮虔温と知覚の相互関係、について調べた。

対象：対象の条件は、母乳授乳を続けて いる、研究への参加を同意した者とした。 今回、得られた対象は20例で年齡範囲は22 葴から39歳であり、産歴別には初産15例、 経産5例であった。産褯時期は、産袮1日目 から12週間目の範围にあった。

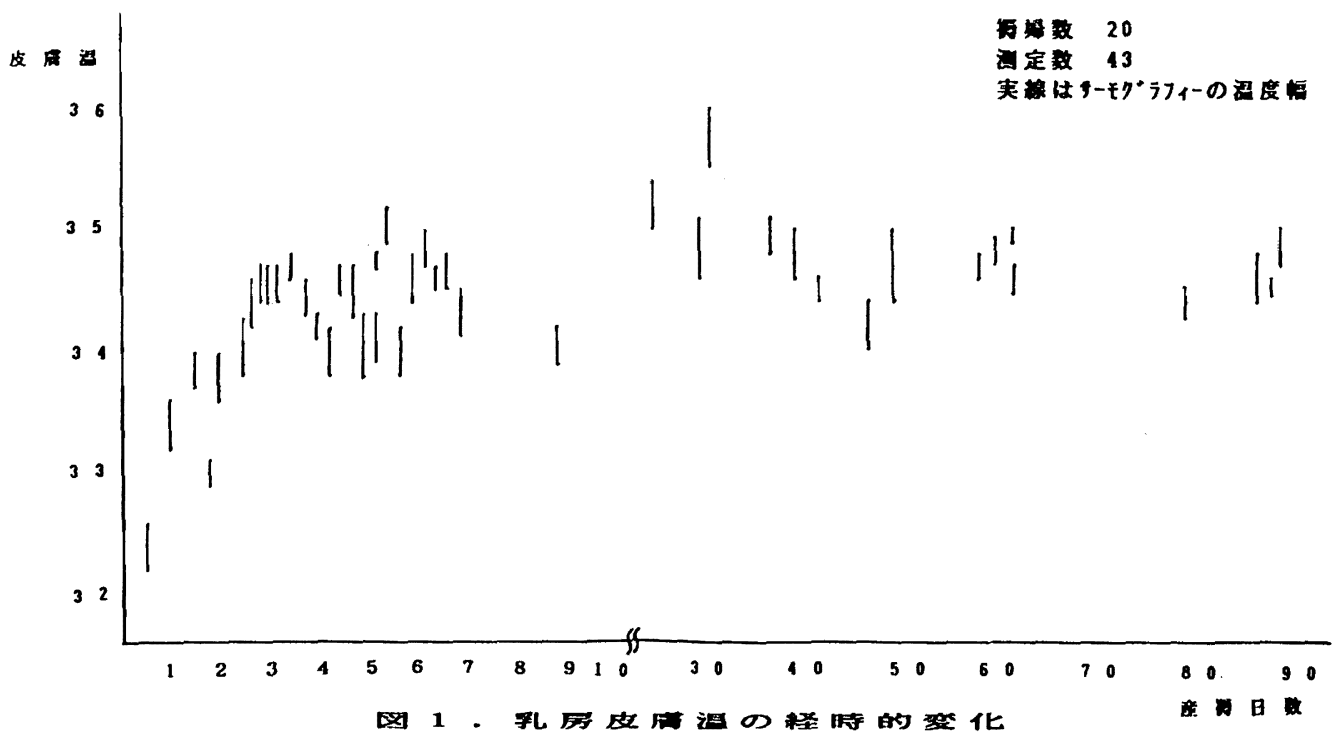

測定場所は、汗のでない快適な室温（25度 前後)とし、風のない状態とした。対象者 は、測定時刻の最低 5 分前には、入室し、 乳房の皮虔を室温に慣らした状態にしてお く。授乳は、自律授乳とする。測定機器は、 医用サーモグラフィ装置、INFRA-EYE1100( 日本光電製)を用い、ポラロイド写真とし て記録した。

主観的㑯面（乳房の知覚）

研究者が作成した乳房の知覚調查票は、温 熱感・充実感・充満感・重量感・拘束感・ 硬度・疼痛・射乳感覚について、それぞれ SD法による、5段階の順序尺度から成る。 皮虐温測定と同時期に、その時の乳房の知 覚を自己記入してもらうよう依頼した。

結果:

1. 乳房皮虔温の経時的変化と知覚

測定回すべての皮慮温を図 1 に表示した。 サーモグラフィの温度表示は、0.1度単位の 色の滤淡で表されている。乳房全体が何度 から何度の幅にあるかを図上に表示した。

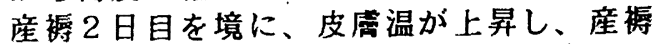
3カ月まで高原状の変化を示していた。

また、同一対象で産裖の 2 時点の経時的 変化を追跡できた者 8 例は、全例が産褯経 過にしたがって上昇していた。上昇幅の大

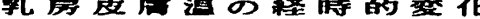

方法：客観的側面（乳房の皮虞温） 
きい5例についてみると、産橱 1 日目と 4 日目0比較が 3 例、産袮 2 日目と 5 日目を、 産褯2日目と6日目を比較した者がれぞ れ1例ずつであった。何れも最初の測定時 点の最高皮虐温を、次回の最低皮属温が上 回る結果であった。

知覚は、最初の測定時点の産渡 $1-2$ 日 目では、温熱感、硬度、充実感ともに「普 通」とするものが多く、次回の産榞 5-6 日目には温熱感、重量感、充実感、張りつ めた感じを「非常に」感じている者が多か った。

2 . 皮虜温変化と知覚

同一対象について、授乳前後の変化を追 跡できた者は11例であった。事例別にみる と、授乳前後で変化が認められなかった例 が6例、授乳後にわすかか皮虔温の变化が 認められた例が 5 例であった。知覚として は温熱感の変化は少なく、授乳後に、充満 感や拘束感が軽滅していた。

3. 吸てつの十分性と皮居温の差

授乳後に皮虔温が左右で差の生じた事例 の11例を図 2 に示した。母親が主観的に十 分吸てつしたと知覚した方の皮虔温が、そ うでなかった側よりも、皮虔温が低い事例 がa-g群である。知覚としては、温熱感には 変化は認められなかったが、充実感や硬度、 响束感が何れも軽诚し、解除されていた。
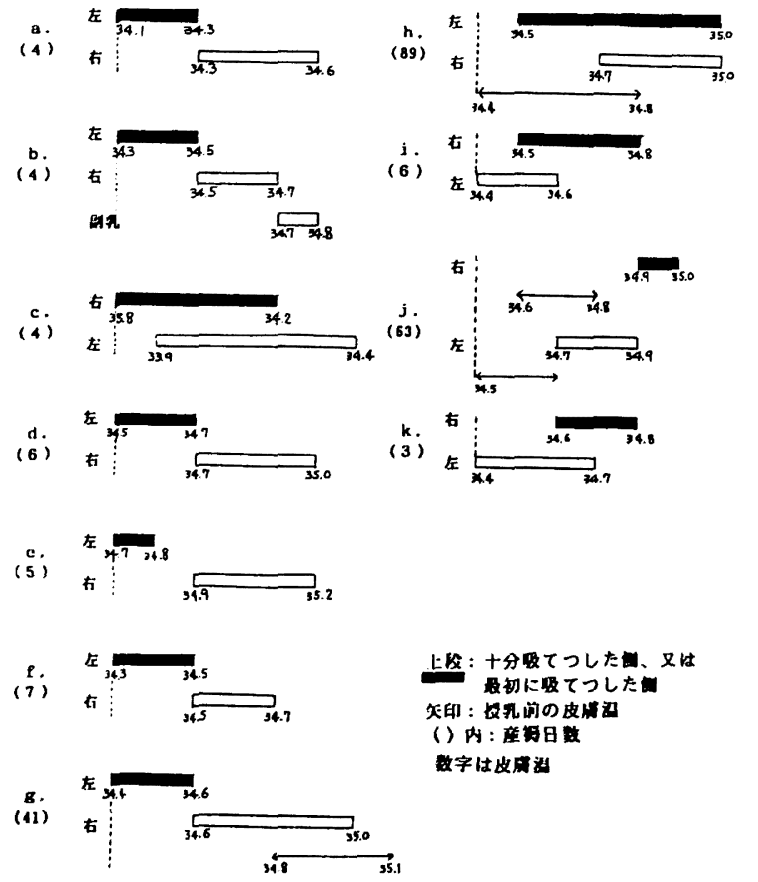

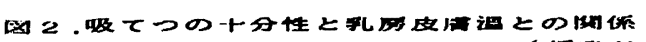

事例h-k群は、最初に吸てつした方の乳房か、 そうでない乳房よりも皮虔温が高くなって いた事例群である。

考察：1.皮虎温の変化

皮虏温の経時的変化は、分婏直後のIリコ” ージメント前と、エンゴージメント以後の乳汁の排出 時点の比較では、皮虐温の上昇が明かであ った。皮虏温は皮虔血流量を反映する定性 的な指標と考えられるが、産裖初期の乳汁 産生過程の変化を示すものではないだろう か。いわゆる中間温領域は皮虔温32-33度の 間にあるといわれているが、乳汁産生に伴 う皮虔温の上昇が明らかとなった。また、 その上昇率の勾配は、産裪日数によって異 なることも示唆された。

授乳前後の乳房の皮虔温の変化は小さく、 乳房腺房への血液供給の変化は、授乳每の 変化として、皮虔温には反映されなかった。 予想しなかった結果は、克の十分な吸て つによる乳汁の排出か、、該当乳房の皮慮温 を下降させた例と、逆に上昇を招いた例が 存在した点である。乳汁の排出が乳房の血 夜偱環動態にどのような影響を及ぼし、皮 虔温に変化をもたらしたのか今後の研究が 必要である。

\section{2 . 乳房の知覚}

乳房の知覚は、皮虔温の変動に呼応した 変化を示していた。乳房の皮虔温の左右美 を生じた事例ではその差異が0.2度前後であ っても明白にその違いを知覚していた。知 覚怙個人差が大きいが、温熱感が中心的な 感覚ではなかった。授乳前後の皮虔温の変 化がわずかな状況においては、硬度や充実 感、張りつめた感覚のほうがより敏感にそ の違いを反映していた。特に、座裾 1 カ月 以降の袮婦においては、授乳前後での温熱 感の変化はほとんど知覚されず、それ以外 の拘束感や压迫感などの感賞で表現してい た。

結呤 :

1.乳房の皮虔温の経時的变化では、エリ゙ ージメッ前後の比較で、32-33度か 534-36度 に上昇していた。しかし、授乳前後での变 化は小さかった。

2. 児の吸てつが十分であった乳房と、そ うでない乳房とでは、皮层温に差が生じて いた。

3. 乳房の知覚は、皮虔温の変化状況と呼 応していた。知覚は温熱感のみならず、重 量感、充実感、硬度、張りつめた感じ、拘 束感によって表現されていた。 


\section{8 裖婦の授乳動作における実証的研究}

一いすの寸法からみた筋電図評価一

\section{1.はしめに：}

私達は授叱行為専用いすの設計計画を看護 学および建築学を考虑した人間工学的見地か ら研究を進めてきている，今回，いすの寸法 性の娭証を目的に筋電図特性から投拜行為に おいてどのように筋活動が変化するか比較実 略し評価した。

\section{2 。実聁要領 :}

$\mathrm{K}$ 病院生理学検査室にて産病 4 日目に産裤 いす，産被5日目に実聡いすで実驗。'90年1 1月実施。対象は正常分娭した䅅産婦 3 人(平 均身長 $157.5 \mathrm{~cm}$. 平均座高 $83.5 \mathrm{~cm})$ とその新生览. いすの条件は(1)背板付き馬路形産裖いす(ア 卜ム $K K$ 製造）で座面高 $430 \mathrm{~mm}$ - 座面角度 0 度。 背板角度 0 度. (2)実験いすは至遵寸法と判定 した座面高 $300 \mathrm{~mm}$. 座面角度 5 度・背板角度 2 5 度（第 3 回日本助産学会・第 $31 \cdot 32$ 回日本母 性衛生学会報告）。授䄽行為の条件は通常の 横抱きの授叱，排気は母親の右眉上に新生児 の顔を面きタッチンクは右腕横抱きとした。 筋電目模查条件は表面筋電目法で左右各 $12 \mathrm{CH}$ の筋肉群より双極誘導にて筋電龱娭出，部位

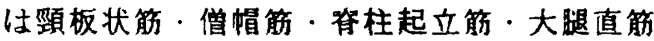
腓腹筋・前頚骨筋の6つの主要筋群。実騂 デー夕解析装置は医用デー夕処理装䈯ATAC-3 700 ，筋電㘝解析ソフトQP-720M，収録時間は 授叱行為の一連を柊了まで連哱的に行った。 筋活動量は各行為20秒間をヒストクラム解析 し定量評価した。

3. 楛果と考察:

（1）新生児を抱かずにリラックスした座位安静 時の筋活動の変化を6つの主要筋肉群の総和 の平均値（目 1 ）でみると，実験いすは536. 00スパイク（以下 $\mathrm{s}$ と略）で筋活動量は僅か であるが既製産袮いすは1463.33 $\mathrm{s}$ と多く実駼 いすに比べ 3 倍を示し，産褯いすの方が筋負 担が多いことが分った。

（2）授叱動作別では（困1）右叱房による授乳

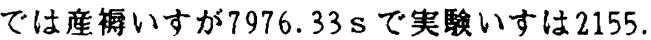

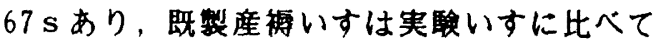
3.7倍多い，左嗮房による授叱は産褾いすでは $12154.00 \mathrm{~s} て ゙$ ，実験いすの3090.00 s に比べて

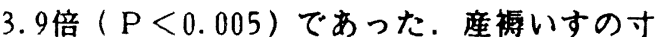
法では粎 4 倍の筋負担を与えて投叱を行って いるといえる。左・右授䄽による筋活動量の
後藤幸子，大川洋子（福井県立短期大学）

左右差が大きいのが産裤椅子である。これは いすの寸法が榞婦の体格に不透なため不必要 な筋肉の活動を惹起し筋活動量が增加したも のと推察される。排気行為では産痛いすは66 $45.33 \mathrm{~s}$, 実臨いすは5857.33 sで筋活動量の 差は㒖かであった。タッチング行為では産褯 いすが8185.67 s で実験いすの4260.33 $\mathrm{s}$ に比 べ䄪 2 倍であった．いすの寸法性に最も影䪪 する動作は授叱の行為，次いでタッチング行 為であった。既製の廒裤いすの寸法性では授 叱・排気・タッチングのすべての授涀動作に おいて実歌いすの寸法性に比べ筋活動量が多 く，袮婦に筋負担を強く与えていることが分 った。

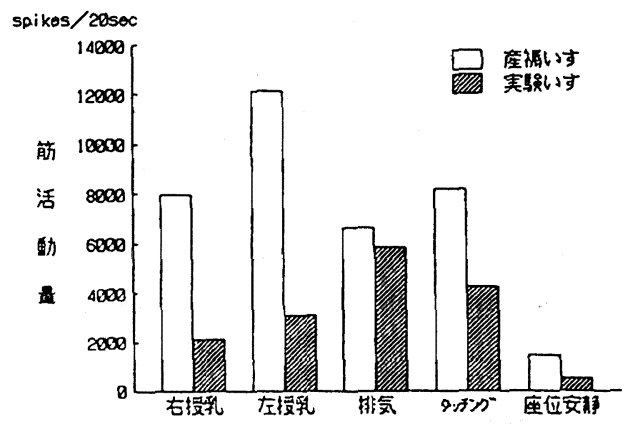

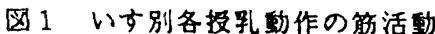

（3）授㔀行為を動作別に各筋肉群の筋活動量を 産裋いすと実駼いすで比較した（図2）。左 乳房による授叱の行為では，産裞いすで最も 筋活動量が多かったのが僧帽筋で3123.7 s. 次いで前領骨筋 $2849.3 \mathrm{~s} \cdot$ 腓腹筋 $2562.0 \mathrm{~s} \cdot$ 顁板状筋 $2374.7 \mathrm{~s}$ ・大腿直筋 $19.3 \mathrm{~s}$ であった。 実歌いすで最も多かったのは頸板状筋で1560。 $3 \mathrm{~s}$ で次いで僧帽筋 $1351.3 \mathrm{~s}$. 前媔骨筋 15.6 $\mathrm{s}$ ・腓腹筋 $13.3 \mathrm{~s} \cdot 大$ 大腿直筋 $6.6 \mathrm{~s}$ であった。 既製産褯いすによる左授乳は冒・下腿部の筋 肉に負担を多く与えていた。実験いすに比べ 座面高が $130 \mathrm{~m}$ と高いことから僧帽筋 ·腓腹 筋・前頸骨筋の活動量が增加したものと推察 される．友投叱の行為では，産裤いすで最も 筋活動量が多かったのが僧帽筋で1958.0 s 次 いで合柱起立筋 $1869.3 \mathrm{~s} \cdot$ 頸板状筋 $1650.3 \mathrm{~s}$ ·前領骨笳 $1397.0 \mathrm{~s}$. 腓腹筋 $1062.3 \mathrm{~s} \cdot$ 大腿 直筋39.3 sであった，実驗いすでは僧帽筋 が $1121.3 \mathrm{~s}$ で次いで頸板状筋 $733.3 \mathrm{~s} \cdot$ 冷柱起立 

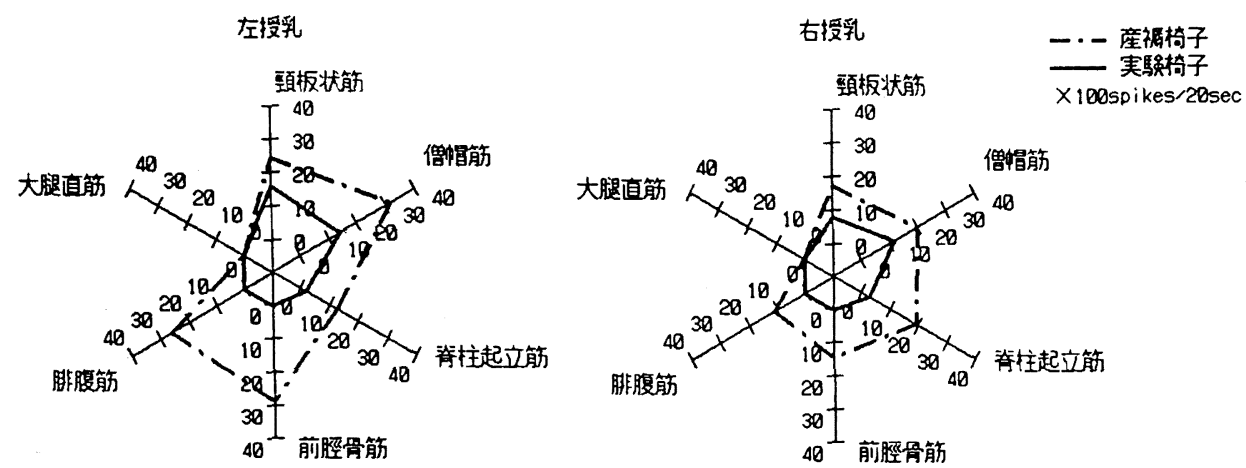

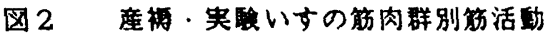
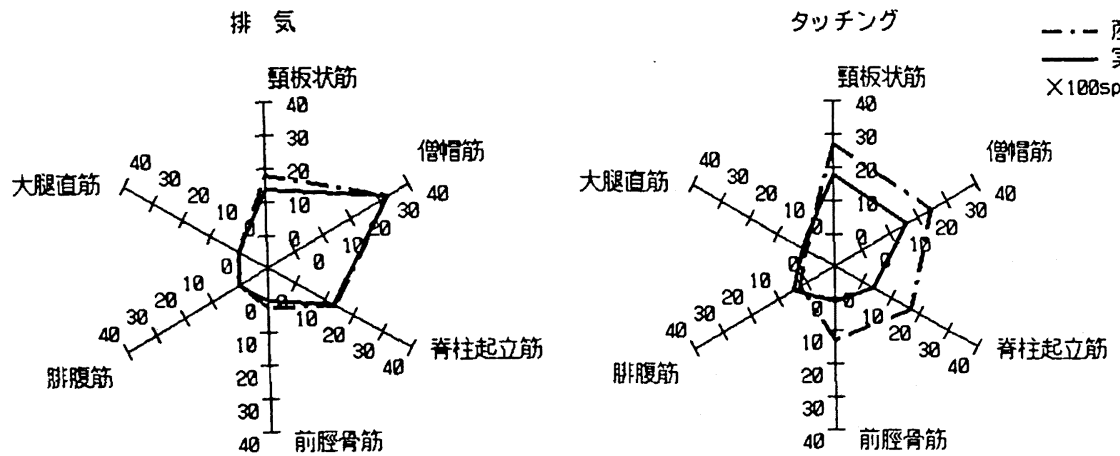

图3産梅・実涘いすの筋肉群別筋活動

注）比較を谷易にするため座標狪の 原点をー 10 とした

筋 $255.0 \mathrm{~s} \cdot 大$ 大煺直筋 $21.7 \mathrm{~s} \cdot$ 前頸骨筋 $15.0 \mathrm{~s}$

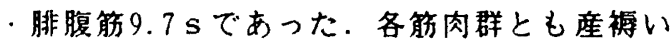
すの筋活動量が多く箭負担が大きい，産病い すは実験いすに比へ前頚骨筋・腓腹筋 が180 倍以上, 脊柱起立筋が䄪 9 倍を示した。排気 行為では，産褯いすと実駼いす（图3）と比 べると僧帽箭 が3241.0 s - 3241.4 s, 頸板状 筋は1759.3 s・1316.3 s，脊柱起立筋は 1374. $4 \mathrm{~s} \cdot 1262.0 \mathrm{~s}$ と近似した值であった．2脚の いすとも各授叱行為の中で最も筋活動が多か ったのが僧帽筋であった．実験いすが産袮い すに近似した值を示したのは座面角度の影響 とも思われる。（排気行為は座面角度が上が るにつれて筋活動量が多くなる，第32回報告） 合目的性のある安楽な排気の指導により筋活 動の負担を最小限にできるものと思われる。 例えば右腕に新生児を抱き授乳の姿勢と類似 した動作で排気を行うことにより筋負担の軽 減が図れるものとも考える. 次にタッチング の行為では，産榑いすは頚板状筋が2681 sで
筋活動量が最も多く，次いで僧帽筋が $2395 \mathrm{~s}$

·合柱起立筋 $1662 \mathrm{~s} \cdot$ 前頚骨筋 $1258 \mathrm{~s}$ であった。 実験いすは頸板状筋が $1759.3 \mathrm{~s} て ゙$ 最も多く次 いで僧帽筋 が1547 s ·腓腹筋 $421.7 \mathrm{~s}$. 㓌柱 起立筋 $339.4 \mathrm{~s}$ で大腿直筋・前頱骨箭は僅かで あった。産裋いすは実略いすに比べ僧帽・钼 板状筋が1.5倍，脊柱起立筋は 5 倍，前頸骨筋 は最も多く20倍を示した．実驓時の袹婦の意 識によると産褯いすは座面高が高いため踵を 床から離しつま先を足の支持点とし膝を高く し投叱姿势を維持させないと投叱しにくいこ と，実駼いすは全員が座面の高さと背もたれ の感しが丁度良く楽に授乳でき授乳専用いす として非常に良いという評価を得た。

5.おわりに:

既製産䙐いすは過剩な筋柴張を招き不必要 な筋負担を与えて授叱時に座るいすとしては 不向きであることがこれらの実驓結果から明 らかになった．現在試作品を製作しており， さらに具体的に梲証していく予定である。 


\section{9 当院における妊娠中のウエイトコントロールの害態}

一最適母体重増加量の検討一

市立小野市民病院

【緒言】妊娠中の肥满は難産や妊娠中毒症 を誘発する事が知られるようになり，最近盵 渵防止が盛んに叫ばれるようになってきた。 盵满の整害が叫ばれる一方, 妊娠中の体重増 加が少なければ有意に子宮内胎児発育遅延

（ＵＵＧ）の增加が認められるという意見 もある.

そこで、この度私たちはカロリー制限が好 娠分婏に与える影䪪を血色素量と産後の骨密 度を中心に検討を行ない，弤娠中の適切な体 重增加量を算出した。

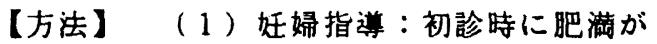
弤赈分婏に与える悪影響を説明し，その後適 宜外来で指導を追加した。母親教室では，前 期・中期で肥渵の睯害について説明を行なつ た。体重増加の著しい妊婦には，栄養士によ る指導も追加した。

（2）正常妊娠分婏例での体重增加：平成 2 年中に当院で分婏を行なった妊婦中(245例)， 妊娠前の体重が明らかな症例で体重増加と新 生児体重の関係を調查した。また，異常分婏

（帝王切開・吸引分娭・陣痛誘発绪使用・要 延分婏）。異常妊帪（双胎・早産・尿蛋白土 以上・下肢浮腫士以上）, 肥渵（妊娠前 $60 \mathrm{Kg}$ 以上又は分婏時 $70 \mathrm{Kg}$ 以上），低出生体重児分 娩・合併症を除いたいわ化る正常妊娠分婏例 での妊娠中の体重增加を求めた。

（3）骨密度と䨘血：平成 2 年以降産後に骨 密度の测定（QＣＴ法）を行なつた弤婦（89 例)で体重增加・血色素量・骨密度の関係を 調べた。

【結果】（1）平成 2 年での母体重增加は 平均 $8.1 \mathrm{Kg}$, 新生児の出生体重の平均は $3080 \mathrm{~g}$ であった（図. 1)．母体重増加と出生児体 重の間には相関は認められなかった。

正常な妊娠経過・分婏経過と考えられた症 例での姡娠前体重は $47.9 \pm 3.88 \mathrm{Kg}$ (平均士標 準偏差），母体重增加は， $7.64 \pm 2.67 \mathrm{Kg}$ で。 身長は157.1土5.1c⿴囗十施あった。これらから求 めた非弤時と分娩時のボディマス指数は19.3 7 と22.47であった。出生児体重は $3121 \pm 302 \mathrm{~g}$ であった。（表. 1)

弤娠中に轻度以上の下肢浮腫・尿蛋白を認 めたにとどまり他に妊娠の異常を認めず，い わゆる自然分娩となった症例でも平均体重增 加は8. $17 \mathrm{Kg}$ であった。
黒田佳子，藤原直美，三村公子，浜本 保

異常妊娠分婏例は，帝王切開（既往帝切： 15例，狭骨盤：1例，軟産道強勒：2例, 胎児 仮死：4例, 高年初産婦：3例, 横位：1例, その他），吸引分婏（7例）等を含んでいる.

(2) 血色素量と妊娠中の体重增加の関倸

(図. 2) ではこれらの間に相関は認められ なかった。また，体重増加と産後の骨密度も

（図.3）相関を認めなかった。

体重の経過から体重 $=46.922+0.079503 \times$

（週数）+0.01621 (週数) ${ }^{2}-0.00018258 \times$

(週数) 3 の 3 次回㷌式を算出し，それぞれ

の莮数での体重分布標準偏差の平均 $4.35 \mathrm{Kg}$ を 增減し図. 4 に示した。

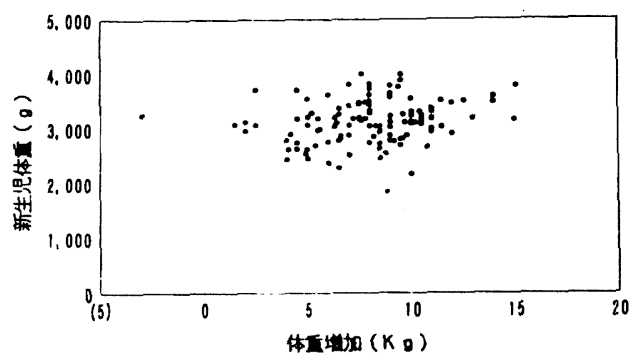

図. 1 母体重増加と出生児体重

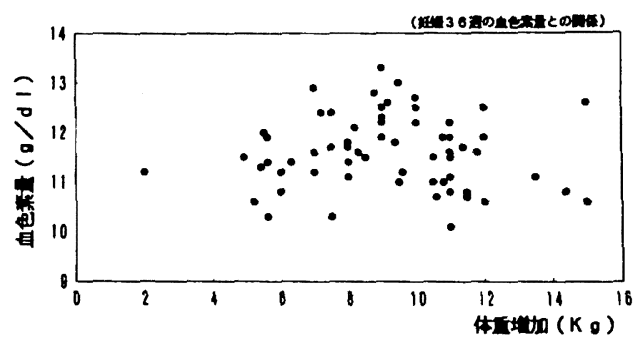

図. 2 母体重増加と血色素量

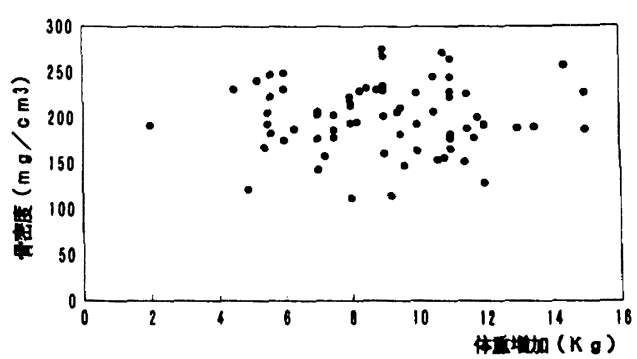

図. 3 母体重増加と産後骨密度 


\begin{tabular}{|c|c|c|c|c|}
\hline & 正常群 & 妹娠中毒症 & 異常分婏 & 盵满群 \\
\hline 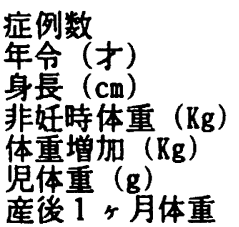 & $\begin{array}{l}47 \\
28.5 \pm 3.69 \\
157.1 \pm 5.1 \\
47.88 \pm 3.88 \\
7.64 \pm 2.67 \\
3121 \pm 302 \\
51.6 \pm 4.40\end{array}$ & $\begin{array}{l}34 \\
27.4 \pm 3.55 \\
156.1 \pm 3.19 \\
49.62 \pm 6.03 \\
8.17 \pm 3.19 \\
3175 \pm 364 \\
51.9 \pm 4.87\end{array}$ & $\begin{array}{l}34 \\
29.1 \pm 4.63 \\
155.3 \pm 4.11 \\
52.95 \pm 8.30 \\
8.32 \pm 2.91 \\
2988 \pm 454 \\
54.0 \pm 7.42\end{array}$ & $\begin{array}{l}12 \\
30.4 \pm 4.10 \\
159.6 \pm 4.92 \\
64.89 \pm 6.45 \\
7.21 \pm 2.71 \\
3327 \pm 404 \\
65.86 \pm 4.12\end{array}$ \\
\hline
\end{tabular}

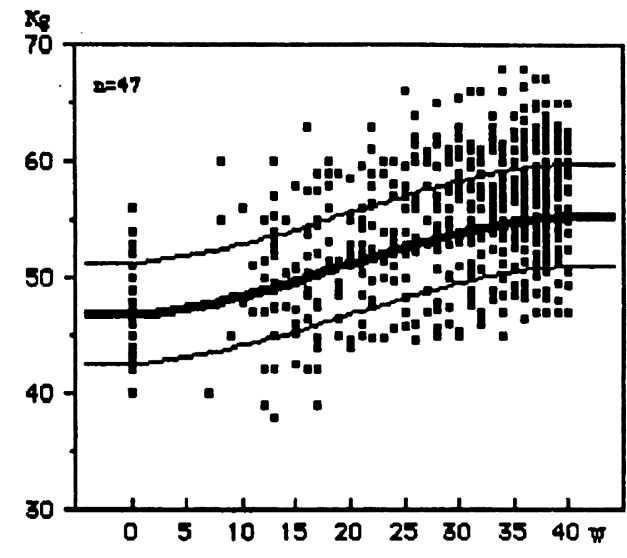

図. 4 正常妊娠分婏例での体重增加

【考察】肥渵が妊娠中の異常・分娩異常は もとより新生児の予後にまで関係するといわ 九るようになり，弤婦の盵满防止に注目が集 るようになった，従来，妊娠中に適度の体重 增加がなければＵＵＲの発生を招くとする 意見や新生児死亡率による検討から適切な体 重增加は10 Kg前後と考えら九てきた。しかし ながら，最近では体重増加を8 $\mathrm{Kg}$ 以内に抑え る方が好ましいとする意見も見られ，体重制 限が妊娠分婏に悪影智を及ほす可能性がない か否かの検討を行なう必要が生じてきた。

姡娠中のウェイトコントロールについて。 現在では医療関係者からの直接指導を受ける 以外に弤産婦を対象とした雑誌等でも盛んに 取上げられている．肥渵の弊害については多 くの報告がなされてきたが, 体重増加を制限 した結果についての報告は殆ど見られない。

日本産婦人科学会栄養問題委員会報告(昭 和 54 年) は。弤帪中の平均体重增加を $11.48 \mathrm{~K}$ $\mathrm{g}$ と報告し、昭和 63 年の報告ではカウブ指数 で4-4.5の増加を平均として挙げている。 こ の值は身長 $158 \mathrm{~cm}$ の女性では10-11.2 Kgに相当 する変化である。

昭和 63 年に助産婦に上る外来指導を開始し 盵渵防止を中心とした保健指導を行なってき た。指導は妊娠初期から行ない, 肥渵が妊赈 分婏に与える悪影帮を説明した。その結果,
平均体重増加は8.1 $\mathrm{kg}$ となり，また正常妊娠 分婏経過をとつた例では7. $64 \mathrm{~kg}$ で全国平均を 約 $3.5 \mathrm{~kg}$ 程度下回り, 軽度の弤娠中毒症症状 は認めたものの妊娠経過に大きな異常はなく 分婏もいかゆる正常分婏となった例でも8.17 Kgの増加にとどまっていた，真柄は妊婦にウ エ1トコントロールを指導し，平均 $8.7 \mathrm{Kg}$ の 体重增加で平均 $3161 \mathrm{~g}$ の児体重を得ることが 出来ると報告しているが, 今回の結果ではこ 九をも下回る事になった。

妊娠中の体重增加を抑えることにより血色 素量と骨密度が影翠を受けるか否かを検討し たが，いずれも体重との相関を認めなかった。 このことからカロリー搷取を抑えても適切な 食事を摄取すれば体重を必要以上に增加させ ることなく分娩に備えることが出来るものと 考えられた。

経済大国となった近年でも，妊娠中には二 人分食べなければならないという迷信ととも に妊赈中のカロリ一付加が成書にも記載され た結果妊婦の肥渵を招いたが，現在では逆に カロリ一制限の必要性が叫ばれるようになっ てきた。当院でも，カロリ一制限の必要性を 妊赈初期から個別・集団指導を通じて頻回に 説明を行なってきた。適切な体重増加につい ての評価は。短期的には妊娠分娩経過・周産 期死亡などから，長期的には母体の罹患率・ 平均余命・児の平均寿命などから考㤁される 必要がある。現在までこれらについて検討さ れた報告はなく今後の課題といえるが，少な くとも現時点では弤娠中に必要な体重增加は 過去に考えられていたよりも予想以上に少な いものと推察された。

参考文献

1)浜本保，萬代喜代美：QＣT法に上る褯婦 骨塩浇度の测定，骨形態計測学会誌。投稿中。 2 ) 黒田佳子, 捠本保：正論が届きにくい習慣 の壁, 助産婦雑誌, Vol. $54:$ No. 10.p. 62-67.1 991

3)真柄俊一：弤娠中のウエイトコントロール と胎児発育の関係。日産婦東京会誌、Vol. 33 . No. 4 . p. $475-478,1984$. 


\section{0 臍帯結禁時期が新生児経過に及活す影響}

\section{尼崎医療生協病院 1 病棟}

[目的]分婏時の滕钼結热洔期については、 従来より腈率拍動の停止を待って結热を行う late clump (以下LC) 法が推奖されて招り 現在もな扣看護・助㓌学の教科䡒には本法か 記截されている。しかし、L C 法は新生児多 血症やそれに由来する黄疸の発症の危險を增 大する可能性があり、近年では児の㚾出後可 及的速やかに膘带を結热する early clump （以下E C ）法を行っている施設が多い。

今回、私達は両法の意義につき再検討を行 い、若干の知見を得たので報告する。

[対象]妊娠・分㚾中を通して暴常を認めな かった当院出生児94例を対象とし．分㚾洔に 任意にEC法またはL C 法により滕带結梦を 行った。今回の検討では、oxytocinなとによ る分姺誘発・促進侧、帝王切開や吸引分姺な どにる分㚾例は除外し、正常経䧑分婏例の みに限って検討を版えた。

対象新生児に対し、生後5日目に行った routine 採血の結果より赤血球数、hematocrit値、hemoglobin值などの血算值、総bi一 lirubin 值の検討を行った。また、生後 5 日 目までの榶液・母乳・人工乳を合わせた総経 口哺乳量と体重变化率についても检討を䛋元 た。体重変化率は、出生時児体重を基韭とし た百分率により检討を行った。

な招、生後5日目までに新生児黄疸により 光線療法を施行した例は、上記の検討対象か 5除外、別飞早胡光線療法施行乐として算出 し検討に倛した。統計学的検討には、 $\mathrm{t}$-榆定 および $\chi^{2}$ 一㭘定を用いた。

[結果] E C 法は45例に、L C 法は49例に施 行した。とのうち。早断光線療法施行例は。
丸本恵子、中井秀代、塩田幸恵、富永容子

E C 群で 4 例 $8.7 \%$ ，L C 群で 9 例 $18.4 \%$ と 後者で有意に高かった。とれらを除く、E C 群41例、LC群40例を对象に5日目までの総 経口哺乳量、体重変化率や血液所見を検討し

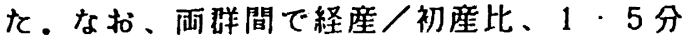
後のApgar scoreに有意差はなかった。また

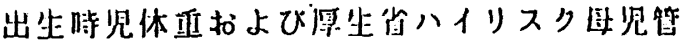
理研究班の基染"比基うく relative birth

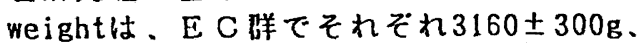

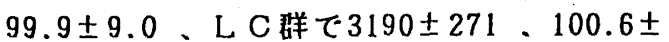
7.6 と若干L C 群で高值であったが、ともに 有意差は認めなかった。

表比生後 5 日目の晌液所見の結果を示す。 赤血球数、hemoglobin值乃 hematocrit值は。 いずれもLC群で有意に（ $p<0.001 ）$ 离く。 L C 群でのhemoconcentration の存在が示さ れた。特に、L C 群ではhemoglobin値22.8 $\mathrm{g} / \mathrm{dl}$ 、hematocrit值 $70.2 \%$ とい5、高度の多 血症児がみらた。

生後 5 日目の総bilirubin 值の检討（表）

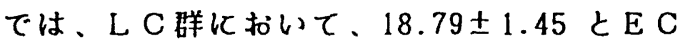
群の $16.58 \pm 1.64$ に比へ有意に（p<0.001） 高值であった。また、総bilirubin 值20.0 $\mathrm{mg} / \mathrm{dl}$ 以上の高bilirubin 峴症贤は、E C 群 の 3 例 $7.3 \%$ に対し、LC群では11例 $27.5 \%$ と有意に多くみられた。

生後5日目までの総経口哺乳量（図1）の 検討では、生後2 日目以降 5 日目まで E C 群 で哺嗮量が多い傾向がみられ、特に4日目で は有意に $(p<0.05)$ 多かった。

また、生後 5 日目までの体重变化率の検討 結果を図 2 に示す。L C 群では、生後4日目 まで低下を続け5 日目に至って若下の上昇侕

表生媵 5 日目に扣ける血液所見

\begin{tabular}{lcc}
\hline & Early Clump & Late Clump \\
\hline T. Bilirubin & $14.75 \pm 3.55$ & $18.09 \pm 2.69^{*}$ \\
R B C & $509.8 \pm 49.2$ & $564.2 \pm 46.4^{*}$ \\
Hematocrit & $51.91 \pm 4.98$ & $58.00 \pm 4.50^{*}$ \\
Hemogrobin & $16.58 \pm 1.64$ & $18.79 \pm 1.45^{*}$ \\
\hline & $-46-$ & $*$
\end{tabular}


图1生後日数と総経口咘乳奛

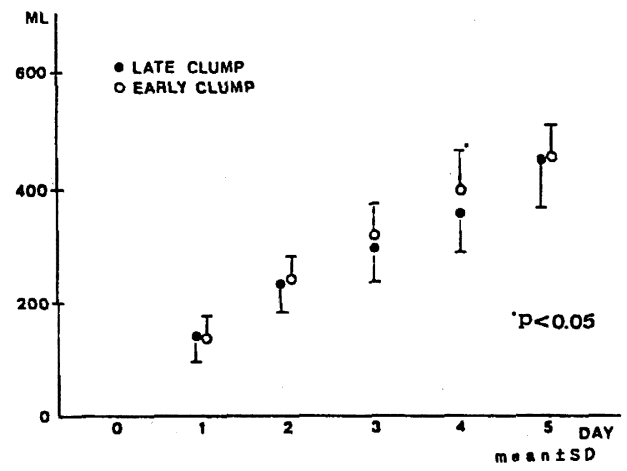

向に枟ずに至った。一方ＥＣ＼cjkstart群では、生 後2 日目に樶低值を記録した後、㮌調に上䒜 していた。また、生後 2 日目以降日を追ろに 連れ、E C 群と L C 群との体重差か增大して いき、生後 5 日目には有意に（p<0.01）E C 群で体重が多かった。

図2 生後日数と呪休重变化高

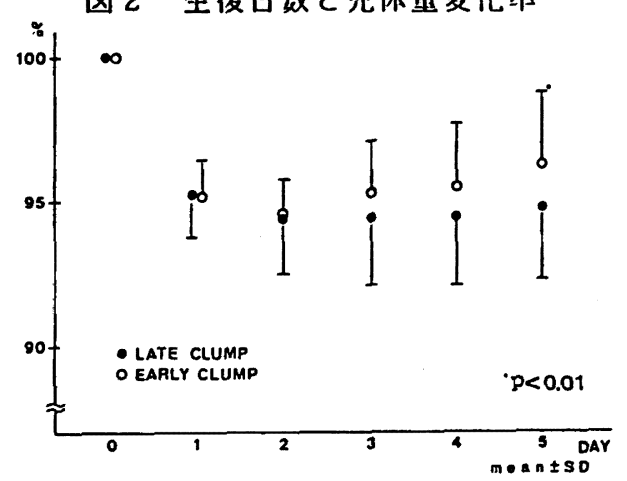

[考察]分娭洔の滕嬊結㷫洔期については。 E C 法の有用性が言われて久しいが、現在に 至るまでE C 法、L C 法のいずれが有用であ るのか、結論は明らかとはなって扰らず、各 施設あるいは分㚾取扱者により翼なるのが現 状である．LC法では多量の胎盤内迈液が新 生児に移行するので、新生児多血症や新生児 黄㾝発症の危険因子となるととは明らかであ る。一方、E C 法では、出生後急速に破壊さ れる胎児性hemoglobinの消失に対する予借能 カの低下を来し、新生児霓血の発症要因と成 り得るとも考えられる。したがって、その選 択には慎重な検討が必罂と思われる。

今回の私達の検討によれは。。生後早朝（5 日目以前）飞光線療法の道応となった新生児 黄疸の発生率およひ生後5日目に扣ける血清 総bilirubin 值は、L C 群に扣いて有意に高 く、LC法が新生児茫㡺発店のrisk factor
であるととは朋らかである。また、L C 胖で

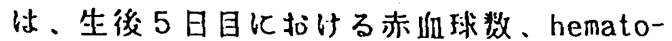
crit値やhemoglobin值も。LC群に扣いて有 意に高く、L C 群に扰ける血清総bilirubin 值の上昇は、胎盤内血液の新生児への流入に よる新生児多血症に由来すると考えるととに 問題はない。

さらに舆味深いととは、生後2 日目以降の 総経口哺乳量が $\mathrm{E} C$ 群において多く、それを 反咉して出生後の休重減少の回復も E C 群に 扣いて良好であるととである。とのととは、 単に血清総bilirubin 值の上㫤による哺乳力 の低下と考えるよりも、多伹症による峏液粘 度の上昇が末梢循愣不全を招き、泪化管の娧 動の低下ゃ中枢神経系の抑制による総合的な 結果であるとも考元られよう。

少数例の検討ではあるが、E C 法により結 禁した腾带打よひ胎盤には約30〜 50m1の邀残 血液かみられて扰り、とれが全部新生児に流 入するわけではないとしても、児の循現系に とっては相当な負荷と成り得る。実際、E C 法の児と L C 法の児の平均体重差30g は、乙 の流入衂液量に由来する可能性もある。

一方、今回の检討では朋らかな目血例は認

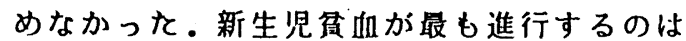
生後 $2 \sim 3$ 週問頃とされるととから、今回の 5 日目の採血では不充分であり、より長期の followが必要とも考えられる。しかし、新生

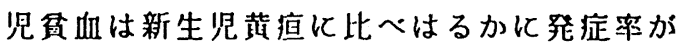
少ないととを考えれは、: 新生児黄㡺の発症予 防に主哏を置き、E C 法を用いるととに何ら 問題はないと考えられる。新生児多血症は、 必ずしも重第な症状を来さないため軽視され がちではあるが、多血症児では成長後のIQ 低下など2り報告されておりり E C 法の有用 性は明らかである。

[結諭］(1)L C 群では、E C 群に比へ、伹清 総bilirubin 值やhemoglobin值などが有意に 上昇していた。ⓁC磍では、E C 群に比べ 生後 2 日目以降の総経口哺乳量や体重の增加 乘が高かった。 (3) E C 法の有用性が強く示唆 された。

\section{参 考 文 献}

1）仁志田博司ほか：日本人の胎児発育曲線 （出生時体格基染曲線）

新生児誌 20：90-97 1984

2) Delaney-Black $V$. et al : Neonatal hyperviscosity association with lower achivement and $I Q$ scores at school age Pediatrics $83: 662-6671989$ 